\title{
Tacit knowledge, as a source of competitiveness: case study
}

\section{El conocimiento tácito, como fuente de competitividad: caso de estudio}

\author{
RIVERA-ACOSTA, Patricia †*, MARTÍNEZ-TORRES, Rosa Elia and OJEDA-GUTIÉRREZ, \\ Maricela
}

Tecnológico Nacional de México, Instituto Tecnológico de San Luis Potosí, México.

Universidad Politécnica de San Luis Potosí, México.

\author{
ID $1^{\text {st }}$ Author: Patricia, Rivera-Acosta / ORC ID: 0000-0002-8254-0005, Researcher ID Thomson: X-2388-2019, CVU \\ CONACYT ID: 232611
}

ID $1^{\text {st }}$ Co-author: Rosa Elia Martínez-Torres / ORC ID: 0000-0001-8936-9207, Researcher ID Thomson: X-3124-2018, CVU CONACYT ID: 953355

ID $2^{\text {nd }}$ Co-author: Maricela Ojeda Gutiérrez / ORC ID: 0002-4655-2391, CVU CONACYT ID: 740613

DOI: $10.35429 /$ EJS.2021.15.8.27.33

Received July 25, 2021; Accepted December 30, 2021

\begin{abstract}
In the society of the XXI century it is generally accepted that a new intangible resource of organizations is knowledge, in addition to the other existing resources: human, capital, raw materials and equipment. This is particularly true in a knowledge-based society and economy, where knowledge has become an invaluable medium for all organizations, particularly businesses. The objective of this paper is to make a diagnosis to describe how to apply knowledge management in the family business Campechanas la Escondida de la Trinidad. This project is based on a case study methodology, with a descriptive type of research; the collection of information uses as instruments with a qualitative approach, observation and interviewing. The results obtained show a dependence on the tacit knowledge possessed by bakers who apply in the artisanal process, in addition to family members, lack human talent management, formal training and innovation, which has limited their competitiveness.
\end{abstract}

\footnotetext{
Competitiveness, Technology management, Knowledge management, Tacit knowledge
}

\begin{abstract}
Resumen
En la sociedad del siglo XXI es generalmente aceptado que un nuevo recurso intangible de las organizaciones, es el conocimiento, en adición a los otros recursos existentes: humano, capital, materias primas y equipo. Esto es particularmente cierto en una sociedad y economía basada en el conocimiento, en donde éste se ha convertido en medio invaluable para todas las organizaciones, en particular para las empresas. El objetivo de este trabajo es realizar un diagnóstico para describir la forma de aplicar la gestión del conocimiento en la empresa familiar Campechanas la Escondida de la Trinidad. Este proyecto tiene fundamento en una metodología de estudio de caso, con un tipo de investigación descriptivo; la recolección de información utiliza como instrumentos con enfoque cualitativo, la observación y la entrevista. Los resultados obtenidos muestran una dependencia en el conocimiento tácito que poseen los panaderos que aplican en el proceso artesanal, además los miembros de la familia carecen de gestión de talento humano, capacitación formal e innovación, lo que ha limitado su competitividad.
\end{abstract}

Competitividad, Gestión tecnológica, Gestión del conocimiento, Conocimiento tácito

Citation: RIVERA-ACOSTA, Patricia, MARTÍNEZ-TORRES, Rosa Elia and OJEDA-GUTIÉRREZ, Maricela. Tacit knowledge, as a source of competitiveness: case study. ECORFAN Journal-Spain. 2021. 8-15:27-33.

\footnotetext{
* Correspondencia del Autor (E-Mail: patricia.ra@slp.tecnm.mx)

$\uparrow$ Researcher contributing first author.
} 


\section{Introduction}

The results of a case study carried out in 2020 in a family located in Santa Maria del Río, municipality of the estate of San Luis Potosí, Mexico, are shown. The objective of this paper was to make a diagnosis to describe how to apply knowledge management in the bakery Campechanas la Escondida de la Trinidad.

Micro, small and medium enterprises (MSMES) play a crucial role in the economic dynamics, and they are the benchmark for development consolidation. The trade liberalization has caused several nations to try to become more competitive throughout their productive and business sectors; to make this, it is necessary to take three key elements into account: innovation, science and technology. Competition encourages to consolidate local companies so that their products or services become a reference at the national level, in the first instance and on second place, at the international level.

Currently, there is an intense transformation that requires companies to make strategic decisions to be competitive and to be able to remain in the market in the short, medium and long term. For this reason, it is necessary to comprehend that the knowledge which underlines companies will allow them to face the challenges of their dynamic and competitive environment, to adapt, first to the local economy and finally to globalization (OECD, 2007).

\section{Background}

Micro, small and medium enterprises (MSMES)

MSMES play a very important role in the economy of the countries, based on: job creation, contribution to GDP, sources of entrepreneurship, job providers, etc. The National Survey on Productivity and Competitiveness of Micro, Small and Medium Enterprises (ENAPROCE -by its acronym in Spanish-, 2015) refers that, of the total of these, $97.6 \%$ are considered micro enterprises and account for $75.4 \%$ of the total employed personnel. Followed by small enterprises with $2 \%$ holding $13.5 \%$ of the employed personnel; medium enterprises represent $0.4 \%$ of the economic units and hold just over $11 \%$ of the vacancies filled (Graphic 1).

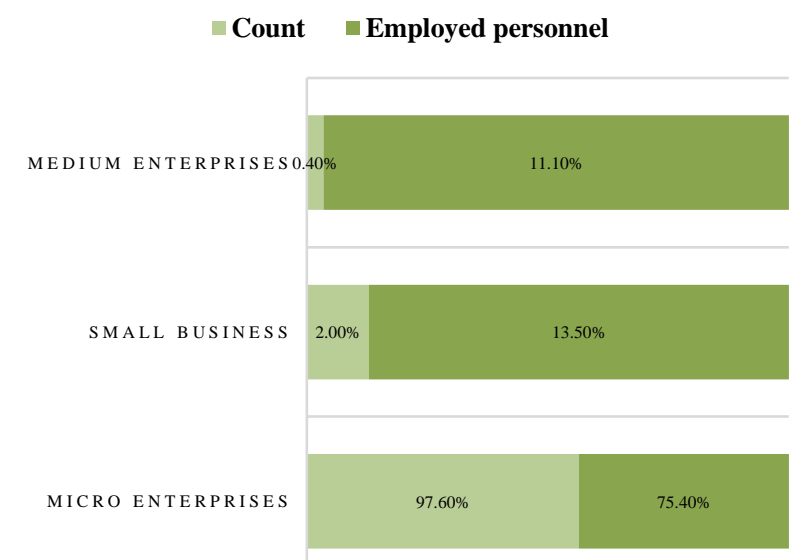

Graphic 1 Distribution of the number of companies and total employed personnel by company size.

Source: own elaboration based on (ENAPROCE, 2015.)

Financing is a key element for business growth, particularly for MSMEs. In Mexico there are four million 057 thousand 719 microenterprises, of which $74 \%$ would not accept financing; it can be noted that this lack of financing has been an obstacle to its growth and permanence in the market (ENAPROCE, 2015 and 2018).

There are multiple challenges faced by micro enterprises in Mexico, among them, the lack of training, in which $65.6 \%$ of these, consider that the knowledge and skills they have, are adequate; problems in the production process represent $47.6 \%$ without solution actions; $65 \%$ do not have indicators to evaluate their performance, see graphic 2 .

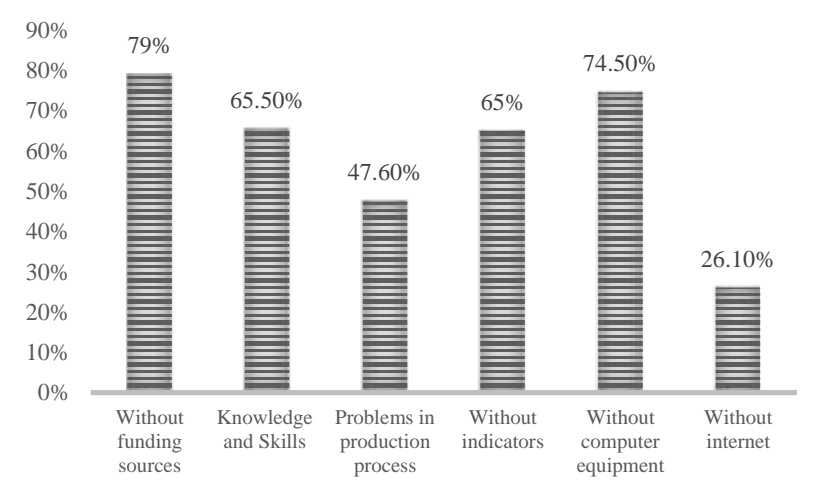

Graphic 2 Challenges for Micro Enterprises in Mexico Source: own elaboration based on (ENAPROCE, 2015)

Other figures to consider are: $60.1 \%$ of micro companies consider that bank loans are expensive and $79 \%$ do not have financing; $74.5 \%$ do not use computer equipment and only $26.1 \%$ have internet access. Given these figures, there is a strength, since $85.3 \%$ of microcompanies express growth intentions. 


\section{Theoretical framework}

\section{Competitiveness}

Hernández (2000) mentions that there has not been reached a satisfactory definition of competitiveness due to the number of factors it includes. Competitiveness at the macroeconomic level, regardless, expresses it as "the ability of the companies to sell more products [...] and to maintain -or increase/ its participation in the market (open and competitive), without sacrificing profits". Likewise, it divides the factors that affect competitiveness at the level of individual companies into: (1) factors that influence the cost of inputs, (2) factors that determine the efficiency in the use of the same inputs and (3) factors related to the prices, quality and differentiation of products generated by the companies, such production technology, normalization and standardization of processes and the certification of the levels reached.

Other authors (Benzaquen, Del Carpio, Zagarra y Valdivia, 2010, p.7) define regional competitiveness as a measure of their way to manage resources and abilities to increase business productivity and the well-being of its population.

Competition in many industries around the world is changing, likewise the pace is accelerating, so that the leaders of organizations require to give value to innovation, response capacity, organizational flexibility, diversity, technology, knowledge management, use of ICT and challenges of the global economy (Rubio and Aragón 2002; Esser, Hillebrand, Messne \& Meyer-Stamer 1996).

There are several success factors in which they coincide: Human Resources management and personnel training, marketing abilities, quality, innovation, technological resources, information systems, financial management, cultural values, organizational structure, know how (tacit knowledge), management capacity, better practices in the complete production cycle, among others (Ibidem).

\section{Technology management}

Technology is the combination between skills and knowledge, capabilities, techniques, materials, machines, computers, tools and more equipment that people use to transform raw materials, problems and new ideas into valuable goods and services (Jones, 2013, p. 240).
According to (Valdés, 2009), technology is defined a a method or procedure to create something, considering the means (instruments, tools, equipment) linked to the kind of materials that are transformed and to the formal and general scientific knowdlege: company, work group or employee in particular.

Also (Daft, 2011, p.254) expresses that technology refers to the work process, techniques, machines and actions used to transform inputs (materials, information, ideas) into products, goods and services.

In accordance with the definitions proposed, technology is not considered as a single and isolated element, but as a series of interrelated elements with the common objective of satisfying the needs of the clients throughout the product or service. In the words of (Valdés, 2009) it is defined as a technological system (TS).

The administration of a TS is one of the keys to success of companies in the world, a task that is not easy without formal scientific knowledge, however it is a valid alternative to keep or increase the competitive position in the market (Ibidem, p. 5).

\section{Knowledge management}

In the Economy of Knowledge, technology (And the knowledge in which is based on) it is finally recognized as a factor of production in contrast to the traditional economy which only accepts capital and labor as factors (Rodríguez 2010, p. 64).

The consolidation of the economy of knowledge demands its generation and not only its exploitation through a good assimilation of knowledge generated by third parties. Cope (2001) adds that knowledge is essential to the point where the individual ability to process it efficiently is able to provide the company with a commercial difference.

The knowledge based economy was adopted to describe the tendency of advanced economies to contribute more and more to the generation of knowledge, information and highlevel training, as well as a growing need for easy access to all these elements.

Knowledge and technology have become increasingly complex, highlighting the importance of links between companies and other organizations as a means of acquiring specialized knowledge. (OCDE, 2006, p. 36). 
In addition, a knowledge-based perspective highlights the interactive processes by which knowledge is created and exchanged both within and outside companies and with other organizations. Research and development $(\mathrm{R} \& \mathrm{D})$ plays a crucial role in the process of innovation, a large part of the activities of innovation are not based on it, but they require of high-qualified workers, and interactions with other companies and with the public research institutions, As well as an organizational structure which facilitates learning and the exploitation of knowledge.

After having pointed out the relevance of knowledge in the organizational context, it is important to have an overview of how it is acquired, shirt and generated, as well as who determines its kind; for this reflection we have taken up the proposal of Nonaka and Takeuchi (1999), who considered knowledge (explicit and tacit) as the most valuable assets of any organization. Explicit knowledge, usually external to the company, can be acquired throughout books, magazines, technical information, design or machines. The tacit (subjective), internal to the company, is in the mind of the workers.

To acquire, imitate or transfer both types of knowledge it is required of learning processes that involve technical knowledge and also experience, developed by the company (Gómez 2008, p. 27). This tacit knowledge is found in people, it depends on the psychological characteristics of each individual, as well as their experiences. Its transmission can be throughout direct contact with the individual or the observation. Tacit knowledge is based on everything we know and apply automatically, not consciously, also built by a great deal of associations that create new meanings, new ideas and applications of the old (Martínez, 2009).

Explicit knowledge, the objective and rational one, can be expressed in words, sentences, numbers or formulas (it is free of context) and Includes theory, problem-solving manuals and databases (Nonaka y Takeuchi, 1999).

The "organizational knowdlege" (Ibidem), should be understood as "the capacity of a company to generate new knowledge, spread it among the members of the organization and materializing products, services and systems". This vision establishes that the people who make up the organization are the ones who hold the knowledge, which contributes to the actions of the organization.
Individual knowledge is created an expanded through the social interaction between the tacit knowledge and the explicit, throughout the four basic forms: socialization, externalization, combination and internalization, as shown in table 1.

\begin{tabular}{|l|l|l|}
\multicolumn{2}{|c}{ To tacit } & \multicolumn{1}{c|}{ To explicit } \\
\hline From tacit & Socialization & Externalization \\
\hline From explicit & Internalization & Combination \\
\hline
\end{tabular}

Table 1 Spiral of knowdlege creation

Source: Own elaboration based on Nonaka y Takeuchi (1999)

Following this perspective (Ibidem), distinguish between managing knowledge and creating knowledge, the first one works with pre-existing knowledge, whereas to create knowledge it is needed that both kinds of knowledge, the tacit an explicit, interact throughout the spiral of knowledge creation.

\section{Methodological description}

He was developed based on the case study methodology, (Yin, 1994, Tellis, 1997a), with a qualitative approach and following the characteristic of this type of research, according to Creswell (2003, p. 164): "it is presented in its natural setting". Carrying out this study at the company's facilities allowed us to get to know the scenario and participants and get involved in their experiences.

The data collection techniques used for this study where observation and interview. An annexed category of qualitative data used was photography an audio recording of the interview. About the participants and the locations (Ibidem), fours aspects are identified: the setting, the actors, the event and the processes; for the unit of analysis these aspects where categorized.

\section{Interview and observation}

The interview was carried out in the bakery and in the owner's home, where besides listening and corroborating their experience in the business, there were the researchers involved in the anecdotes and history of its ups and downs, the succession and the new administrative forms. In these interviews, recordings of the same are considered for the subsequent analysis and interpretation of the information to complete diagnosis.

The observations mentioned were made at the bakery, paying attention first to the process of production of campechanas in one shift until the end of it with the packaging for sale.

RIVERA-ACOSTA, Patricia, MARTÍNEZ-TORRES, Rosa Elia and OJEDA-GUTIÉRREZ, Maricela. Tacit knowledge, as a source of competitiveness: case study. ECORFAN Journal-Spain. 2021 
The responses from the interview were corroborated by specifying data on the knowledge creation process, from which the production process is developed, the methods of conversion from tacit to explicit knowledge and vice-versa, the work environment, the service provided, the facilities and the way the administration carries out daily activities.

\section{Contextualization of the case study}

The bakery Campechanas Escondida de la Trinidad, is located in Santa Maria del Río, considered a magical town of the municipality of the state of San Luis Potosí, 46km from the capital, where the main economic activities are commerce, crafts and agriculture. In Santa Maria del Río, there are other 24 bakeries that make "campechanas", according to the information available in the State Commission for the Gurantee of Access to Public Information of the State of San Luis Potosí (CEGAIP -by its acronym in Spanish-, 2017). Given the characteristics of this bakery, it is a family business, with 4 workers and the married couple who owns it; established in 1974, it has 45 years of history.

Process, the main product of the unit of analysis

Different types of bread are made, of which the one considered traditional is known as: "campechanas", having become a typical bread from the state of San Luis Potosí. Its elaboration is considered artisan, without electrical appliances, with rustic ingredients and its cooking is in a wood-fired brick oven. In figure 1 , a phase of the production process is shown.

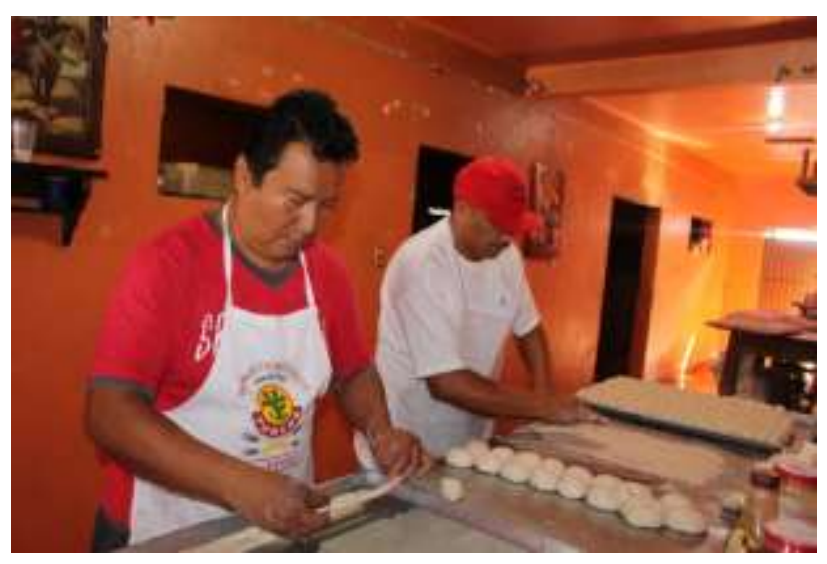

Figure 1 Production process

Source: own elaboration based on the field study

\section{Analysis and results}

From the answers provided by the owners in the interviews, the information obtained from a platform used for the diagnosis is specified:
It is considered a successful company with 45 years of service, it has a system defines as artisanal, where knowdlege, aligned with the "know how" concept, is the original recipe for the elaboration of the products, as it has been inherited from their ancestors.

The business in general, has been carried out "by imitation", since in $1974 \mathrm{Mr}$. Lauro, whom at the age of 17 learned the proper activities by working with Mr. Juan Hernandez, and starts his small business in his own home.

A momentum is recognized in the workers and the intentions from the owners to keep growing. In addition to be willing to adopt administrative system, they have been involved in activities for the regional growth since there are several bakeries, they have created a Cooperative Society. This effort requires that part of their profits are used for that, which they do without an accounting structure, so it is a point to regulate.

In addition, the Cooperative Society is prepared to train staff to increase production and serve the customer with quality service, as well as achieve effectiveness and it's processes to meet the demand since they have not been able to introduce the product in wholesale distribution centers, in which strict requirements must be met, such as having a registered trademark, barcode, product quality certifications, etc., considering that since their foundation, these family businesses do not have financial items for this.

\section{Weaknesses:}

The authors identified, that they do not have qualified bakers and that they have faced frequent absences from work with those hired, hurting the production process. While it is true that they satisfy the demand of the clients, this is possible because the owners get involved in the production so that delivery times are met.

In addition, they do not have a training program for personal who do not have the skills and knowledge ("Know How"); this is, the experience to make "campechanas". Nonaka and Takeuchi argue that knowledge is created throughout the knowledge spiral in the process of continuous creation of new knowledge and its assimilation by the company, at the same time has carried out the transformation of the value creation process, based on knowing how to manage the different types of knowledge and the flows or relationships that are established within and outside of it. 
The individual knowledge, "know how", is created and expanded throughout the social interaction between the tacit knowledge and the explicit one, throughout the spiral of knowledge.

Another weakness is that the owners pay rent for a place that has two brick kilns to satisfy customer demand, this rent is obtained without following a financial pattern.

\section{Opportunity areas:}

The areas of opportunity observed for the unit of analysis are, among others, the way of conducting the business in its administrative practice, the use of information technology, such as having a website.

Also the rules are not well defined formally, logistics is the responsibility of the owner, who sometimes performs multiple tasks: delivery driver, baker, salesperson, delivery service and administrator.

\section{Conclusions}

Santa Maria de Río, Mexico, is a municipality considered as a touristic destination, magical town and cradle of the rebozo, which also offers very attractive landscapes. For this reason, the tradition of "campechanas" finds direct distribution and publicity. It has earned reputation with this product for more than 60 years, being in competition with regions, and national markets such as Tamaulipas, Hidalgo, Querétaro, Aguascalientes.

To improve the productive and competitive performance of the unit of analysis, it is necessary to focus the actions and activities of knowledge conversion, in the development of new abilities and knowledge to optimize and qualify the processes that allow the manufacturing of "campechanas" to respond to the changing demands of customers and markets.

The artisanal production system and knowledge management could be seen in the production process and interview with the owners. In the technology by unit and small batches of the unit of analysis, workshop operations are carried out to manufacture small orders to satisfy the specific needs of the clients. However, production depends on a great deal on the tacit knowledge of the baker, so it is not highly mechanized.
The cooking oven does not obey environmental regulations, it is made rustically with bricks and fired with woods; so there is a risk, if they switch to the use of renewable energy, that the flavor of the "campechanas" changes as well.

In short, the application of strategies, actions, tools that help achieve competitive advantage through competitive success factors are promoted. The complexity generated by globalization, sets new challenges to the unit of analysis; however, the application of the principles and postulates of knowledge management will allow them to better face this challenges.

In the same way, Soto y Barrios (2006, p.2), suggest incorporating activities that generate knowledge in any organization that suits each country and encourages the use of ICTs as a tool for their management; also, that it helps MSMES to raise their levels of competitiveness, Maldonado et al. (Apud Arriaga y Gómez, 2014).

Mexico and its regions, face the challenge of making MSMES competitive and that they incorporate strategies and practices related to knowdlege management that lead them to be more productive and efficient in the context of the factors mentioned in this paper of competitive success, throughout knowledge.

\section{References}

Aponte Rodríguez C.F. Barberi Forero, J. \& Figueroa Figueroa, N.F. (2021). Propuesta de diseño de un instrumento para identificar el Conocimiento Organizacional en la Dirección Nacional de Escuelas (Master's thesis, Maestría en Gerencia de Sistemas de Información y Proyectos Tecnológicos Virtual).

Cope, M., (2001). El conocimiento personal. Un valor seguro. Gestione su conocimiento y sáquele partido. España: Prentice Hall.

Creswell, J., (2003). Diseño de Investigación. California: Sage Publicaciones, Inc.

Cruz, M.F. (2021). Las PYMEs del Sector Automotriz: un estudio de capacidades de innovación dentro del Sistema Regional de Innovación en Aguascalientes. TRANSITARE, 6(2).

Daft, R., (2011). Teoría y diseño organizacional. México, D.F.: Cengage Learning. 
Esser, Klauss; Hillebrand,Wolfgang; Messne, Dirk y Meyer-Stamer, Jörg, (1996). Competitividad Sistémica. Revista de CEPAL, pp. 1-16.

Hernández Laos Enrique, (2000). La competitividad industrial en México. México, D.F.: Plaza y Valdes.

(INEGI), I. (2019). Encuesta Nacional sobre Productividad y Competitividad de las Micro, Pequeñas y Medianas Empresas (ENAPROCE). [online] Inegi.org.mx. Available at: https://www.inegi.org.mx/programas/enaproce/ 2015/ [Accessed 3 Mar. 2019].

Jones, Gareth R., (2013). Teoría organizacional diseño y cambio en las organizaciones. México, D.F.: Pearson.

Moreno Arenas, L.K. (2021). Estado del arte de la trayectoria investigativa de la comunicación organizacional en función de la gestión del conocimiento.

Nonaka, I. y Takeuchi, H. (1999). La organización creadora de conocimiento. . México: Oxford University Press.

OECD, (2006). Manual de Oslo. Guia para la recogida e interpretacion de datos sobre innovacion, Madrid: Grupo Tragsa.

OECD, (2007). Reviews of Regional Innovations Competitive Regional Clusters: National Policy Approaches OECD , s.1.: s.n.

Rodríguez, L. E., (2010). Innovación: Práctica del conocimiento. En: Economía del Conocimiento y Globalización. México. D.F.: Centro de Investigaciones Económicas, Administrativas y Sociales (CIECAS), pp. 6372.

Rodríguez-Lora, V. \& Herrera-Caballero J. M. (2021). El aprendizaje organizacional en instituciones de educación superior. Caso de estudio de un grupo de investigación. Revista Electrónica Educare, 25(3), 1-13.

Rubio, B. A. y Aragón, S. A., (2002). Factores explicativos del éxito competititvo. Un estudio empírico en la pyme. Cuadernos de Gestión Vol. 2. No. 1, pp. 1-15.

Soto, M. y Barrios, F. (2006). Gestión del conocimiento: Parte I. Revisión crítica del estado del arte. [online] Scielo.sld.cu. Available at: http://scielo.sld.cu/scielo.php?script=sci_arttext $\&$ pid=S1024-94352006000200004 [Accessed 4 Mar. 2019].
Tellis, Winston. (1997a). Introducción to Case study. The Qualitative Report, Volume 3, Number 3. Retrieved on February 12, 2009, from: http://www.nova.edu/ssss/QR/QR32/Tellis1.html

Torres, A., J.G., (2009). Teorías sobre el desarrollo económico: una visión regional . En: Identificación de oportunidades estratégicas para el desarrollo del Estado de San Luis Potosí. Monterrey(Nuevo León): ITESM, pp. 127.

UNESCO. (2005). INFORME MUNDIAL DE LA UNESCO. Organización de Naciones Unidas. París, Francia.

Váldes Hernández Luis A, (2009). La administración del sistema tecnológico en las organizaciones . En: El valor de la tecnología . México, D.F. : Fondo Editorial FCA. UNAM, pp. 1-27.

Vega, C.M., Marín, L.M.G., Montoya, L.F.V. (2021). Modelo de gestión de la inteligencia social, apoyado en servicios de social media para transformar las bibliotecas en centros de información y conocimiento. Revista Ibérica de Sistemas y Tecnologías de Información, (E41), 462-474).

Yin, R. K. (1994). Case study Research. California: USA.: Sage Publications.

RIVERA-ACOSTA, Patricia, MARTÍNEZ-TORRES, Rosa Elia and OJEDA-GUTIÉRREZ, Maricela. Tacit knowledge, as a source of competitiveness: case study. ECORFAN Journal-Spain. 2021 